\title{
MANTLE MAGMATIC EVENTS INDICATED BY ZONED OLIVINE AND PYROXENE COMPOSTTIONAL VARIATIONS IN A COMPOSTTE MANTLE XENOLITH FROM LASHAINE VOLCANO, TANZANIA
}

\author{
J.E. Nielson \\ U.S. Geological Survey
}

New information on the petrology and geochemistry of a composite mantle xenolith from Lashaine Volcano, Tanzania, indicates a diverse history for the mantle beneath eastern Africa. The xenolith is composed of websterite and olivine-rich wehrlite. In the wehrlite are preserved contrasting compositional gradients that reflect at least two igneous-metasomatic events in the mantle before entrainment of the xenolith by the host ankaramite lava.

The xenolith consists of olivine-rich spinel wehrlite in contact with spinel websterite. Both rock types are brecciated, but the wehrlite is more extensively disaggregated than the websterite. In one portion of the sample, a fragment of websterite is isolated in wehrlite (Pike et al., 1980). The wehrlite contains olivine porphyroclasts as large as $5.5 \mathrm{~mm}$ across that are surrounded by a finely comminuted matrix of irregular porphyroclastic olivine and clinopyroxene, and rare corroded spinel grains. Euhedral twinned and sector-zoned clinopyroxene neoblasts occur sparsely in the comminuted matrix, along with minute brown spinel neoblasts(?). The wehrlite originally was composed of about $90 \%$ olivine, $9 \%$ clinopyroxene, and a trace of spinel.

A textural transition zone, $4 \mathrm{~mm}$ wide, of clinopyroxene porphyroclasts as large as $2 \mathrm{~mm}$ across in a brecciated wehrlite matrix, separates the wehrlite from the websterite. The prebrecciation even-grained mosaic texture of pyroxene (avg grain size, $1.5 \mathrm{~mm}$ ) is preserved in the websterite. The modal composition of the websterite is $85 \%$ orthopyroxene, $10-12 \%$ clinopyroxene, and $3-5 \%$ euhedral black spinel grains. Clinopyroxene grain margins and some contacts between clinopyroxene and orthopyroxene appear spongy owing to partial melting.

The bulk composition of the websterite is markedly more Fe-rich (Mg-ratio, $\mathrm{Mg} /\left(\mathrm{Mg}+\sum \mathrm{Fe}\right)=$ 0.75) than that of the wehrlite $(0.85)$. This wehrlite composition is in the middle of the range of variation for analyzed spinel-bearing peridotites (dominantly lherzolites) from Lashaine Volcano: the Mg-ratios of seven rocks in the U.S. Geological Survey (USGS) collection range from 0.71 to 0.92 . Garnet or garnet+spinel peridotites from Lashaine are highly magnesian and have Mg-ratios between 0.91 and 0.94 (analyzed specimens in the USGS collection; see also data of Rhodes and Dawson, 1975).

In the composite xenolith the $\mathrm{Fe}$ content of clinopyroxene and small olivine grains decreases across the transition zone from websterite to wehrlite. A contrasting gradient of increasing $\mathrm{Fe}$ content from rims to cores occurs within olivine porphyroclasts in the wehrlite. Systematic electron microprobe (SEMQ) analyses show that clinopyroxene porphyroclasts and neoblasts in the wehrlite have Mg-ratios of $0.87-0.84$, whereas clinopyroxenes in the websterite have Mg-ratios of $0.82-0.80$ (Fig. 1). In the transition zone both the Mg-ratios of clinopyroxenes and the Fo content of small olivine grains decrease with closer proximity to the websterite contact. Gradients also occur in the $\mathrm{CaO}, \mathrm{TiO}_{2}, \mathrm{Na}_{2} \mathrm{O}, \mathrm{Al}_{2} \mathrm{O}_{3}$, and $\mathrm{Cr}_{2} \mathrm{O}_{3}$ contents of clinopyroxene across the transition zone. Orthopyroxene is found only in the websterite, and has Mg-ratios similar to the clinopyroxenes. The scatter in Figure 1 is due to large inhomogeneities in the pyroxene grains.

Large and small olivine porphyroclasts in the wehrlite are reversely zoned. Normally the rims are relatively magnesian ( $\mathrm{F}_{89.5} \mathrm{max}$ ), and the cores are $\mathrm{Fe}-$ rich $\left(\mathrm{FO}_{81} \mathrm{max}\right.$ ). However, more complex zoning also occurs (Fig. 2). The zoning is not apparent either optically or in SEM images of $\mathrm{X}$-ray spectra. Truncation of the zone boundaries by broken grain margins indicates that the zoning predated brecciation. Matrix olivines adjacent to the porphyroclasts have Fo contents that range from 85.2 to 89.3 , like the relatively magnesian por phyroclast margins.

The compositional gradient in clinopyroxene grains between wehrlite and websterite is one of increasing $\mathrm{Fe}$ enrichment toward the websterite. This Fe enrichment, and the xenolith-in-xenolith texture of pyroxenite in peridotite (Pike et al., 1980), resemble the relations identified in other composite peridotite-pyroxenite xenoliths from basal tic lavas (Irving, 1980; Wilshire et al., 1985) and kimberlites (Harte et al., 1977). The websterite is interpreted to represent a relatively Fe-rich basal tic melt that intruded the more magnesian wehrlite. Reaction between this melt and the more magnesian wallrock converted minerals of the wehrlite in and near the cont act zone to more Fe-rich compositions.

Formation of Mg-rich margins on zoned olivine grains is opposite to the trend that likely would have occurred from reaction between Fe-rich fluid from the websterite and more magnesian olivine grains of the wehrlite. The $\mathrm{Mg}-\mathrm{Fe}$ olivine zoning is accordingly interpreted to have resulted from a 


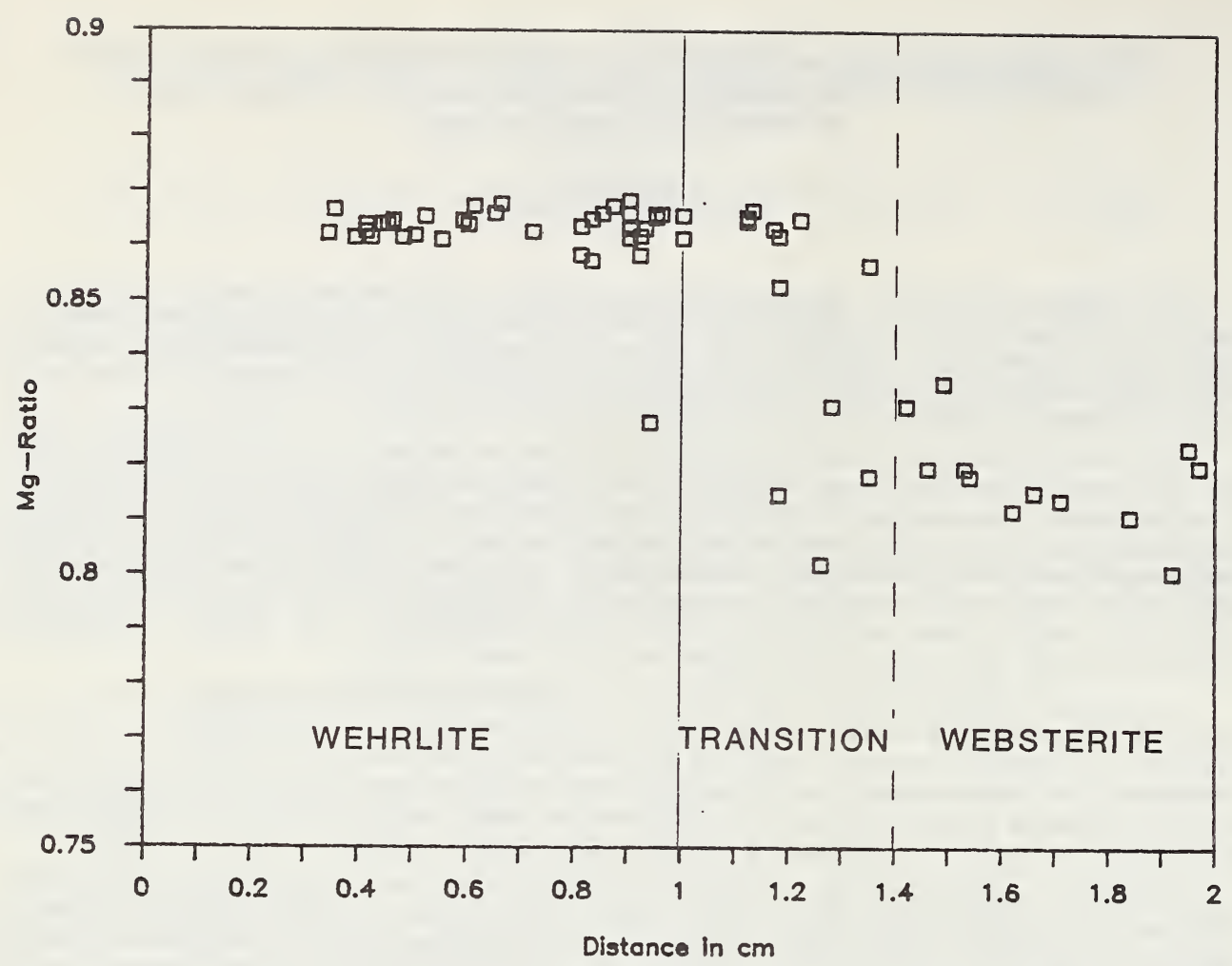

Figure 1. Variations of $\mathrm{Mg}$ and $\mathrm{Fe}$ content (Mg-ratio, $\mathrm{Mg} /\left(\mathrm{Mg}+\sum \mathrm{Fe}\right)$ ) of clinopyroxene across a single probe mount $(2.5 \mathrm{~cm}$ diam). Origin is at edge of wehrlite on probe mount; plane of projection is orthogonal to trend of wehrlite-websterite contact. Solid line is trace of contact between wehrlite and transition zone; dashed line is approximate contact of transition zone and websterite.

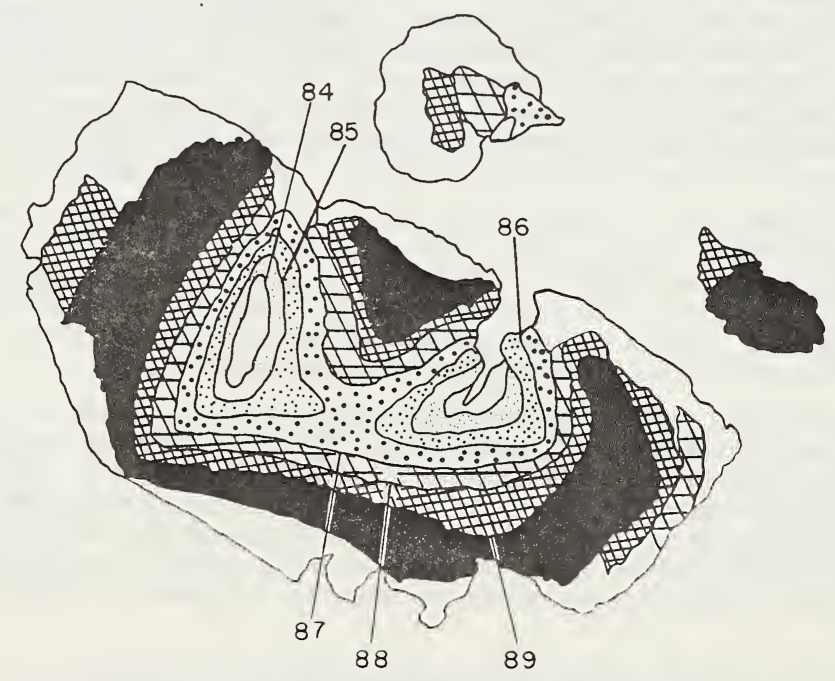

Figure 2. Zoned olivine porphyroclast, $5.0 \times 2.5 \mathrm{~mm}$. Contours in Fo content. 
separate event that extracted Fe from the wehrlite. 'This event could have occurred if small amounts of relatively magnesian melt migrated through the wehrlite and websterite and caused depletion of $\mathrm{Fe}$ in the olivine grain margins. The absence of zoning in pyroxene, in contrast to the strong zonation of olivine, is generally consistent with data on relative rates of sub-solidus diffusion in olivine and pyroxene (e.g., Freer et al., 1982; Smith and Wilson, 1985) and on the dissolution of these minerals in basaltic liquids (Kuo and Kirkpatrick, 1985). Low rates of sub-solidus diffusion of $\mathrm{Ca}, \mathrm{Al}, \mathrm{Mg}$, and $\mathrm{Fe}$ in pyroxenes are indicated by the absence of detectable reactions at high temperature (Freer et al., 1982). Conversely, the experiments by Kuo and Kirkpatrick (1985) suggest that olivine dissolves in basaltic melt more slowly than does clinopyroxene. The relation depends on several factors, including melt composition, mineral composition, and pressure. Experiments suggest that olivine should homogenize rapidly either by reaction with fluid or by subsolidus diffusion (within a year, Smith and Wilson, 1985). Thus, zoning in olivine from Lashaine must have occurred in an event 1 ater than emplacement of the websterite.

From these data, I suggest that the Lashaine composite xenolith represents mantle peridotite wall rock that was intruded in more than one event by basaltic melts of contrasting compositions. In the first event minerals of the magnesian peridotite reacted with Fe-rich fluid that emanated from a basaltic intrusion as it crystallized to websterite. The compositional gradients created by this reaction would require very long periods of time to disappear by subsolidus diffusion between pyroxene grains, whereas the olivine compositions may have become homogenized very quickly; theoretically in less than a year (Smith and Ehrenberg, 1984).

The second event occurred an unknown time later (probably less than $1 \mathrm{Ma}$ ). In this event a more magnesian basaltic melt invaded the rocks and reacted with minerals in both the wehrlite and websterite. Minor inhomogeneities evident in the clinopyroxene porphyroclasts (Fig. 1) may have formed by reaction with this postulated magnesian melt. Olivine apparently dissolves in basaltic melts more readily than pyroxene and this difference may explain why the olivine margins were markedly depleted in Fe. However, because olivine should homogenize very quickly, the preservation of this zoning suggests that the second event occurred very shortly before eruption of the host lava. Both events predated brecciation of the rock association. The brecciation probably occurred as part of the eruptive process. The formation of clinopyroxene (and spinel?) neoblasts must have predated the eruption, but the relation between neoblast crystallization and the brecciation event is unclear.

\section{REFERENCES}

Freer, R., Carpenter, M.A., Long, J.V.P., and Reed, S.J.B., 1982, "Null resul t" diffusion experiments with diopside: implications for pyroxene equilibria: Earth and Planetary Science Letters, v. 58, 285-292.

Harte, B., Gurney, J., and Cox, K.G., 1977, Clinopyroxene-rich sheets in garnet-peridotite: xenolith specimens from the Matsoku kimberlite pipe, Lesotho: Second International Kimberlite Conference, Extended Abstracts Volume, no page number.

Irving, A.J., 1980, Petrology and geochemistry of composite ultramafic xenoliths in alkalic basal ts and implications for magmatic processes within the mantle: American Journal of Science, The Jackson Volume, v. 280-A, part 2, p. 389-426.

Kuo, L. and Kirkpatrick, R.J., 1985, Dissolution of mafic minerals and its implications for the as cent velocities of peridotite-bearing basal tic magmas: Journal of Geology, v. 93, p. 691-700.

Pike, J.E. Nielson, Meyer, C.E., and Wilshire, H.G., 1980, Petrography and chemical composition of a suite of ultramafic xenoliths from Lashaine, Tanzania: Journal of Geology, v. 88, p. 343-352.

Rhodes, J.M. and Dawson, J.B., 1975, Major and trace element chemistry of peridotite inclusions from the Lashaine volcano, Tanzania: Physics and Chemistry of the Earth, v. 9, p. 545-557.

Smith, D. and Ehrenberg, S.N., 1984, Zoned minerals in garnet peridotite nodules from the Colorado Plateau: implications for mantle metasomatism: Contributions to Mineralogy and Petrology, v. 86 , p. 274-285.

Smith, D. and Wilson, C.R., 1985, Garnet-olivine equilibration during cooling in the mantle: American Mineralogist, v. 70, p. 30-39.

Wilshire, H.G., Meyer, C.E., Nakata, J.K., Calk, L.C., Shervais, J.W., Nielson, J.E., and Schwarzman, E.C., 1985, Mafic and ultramafic xenoliths from volcanic rocks of the western United States: U.S. Geological Survey Open-File Report 85-139, 505 p. 